\title{
PEMBERDAYAAN USAHA MIKRO ABON LELE
}

\author{
Romindo M Pasaribu', Audrey M Siahaan ${ }^{2}$ \\ Fakultas Ekonomi dan Bisnis Universitas HKBP Nommensen, Medan \\ romindo.pasaribu@uhn.ac.id ${ }^{1}$,dreysiahaan@yahoo.com²
}

\begin{abstract}
Abstrak
Perkembangan UMKM di Sumatera Utara cukup baik, yaitu sekitar 2.8 juta unit usaha, dan memberikan kontribusi yang cukup baik bagi pertumbuhan ekonomi di Sumatera Utara dan Medan pada khususnya. UMKM dikota Medan tidak dipandang sebagai alternatif, akan tetapi sudah menjadi tulang punggung atau pondasi dari ekonomi di Medan. Terdapat 3 (tiga) hal yang harus diperhatikan dan diperbaiki untuk memperkuat pondasi dari UMKM yaitu, keuangan, peningkatan sdm, dan inovasi model pemasaran. Komunitas Yoppie Belawan merupakan salah satu industri rumah tangga yang ada di Kecamatan Medan Belawan. Tepatnya di jalan Selebes Belawan II, Medan Kota Belawan, Sumatera Utara 20411. Komunitas Yoppie Belawan ini sejak awal tahun 2020 memulai usaha budidaya Ikan Lele. Pada April 2020, komunitas ini memutuskan untuk mengolah daging ikan lele menjadi sesuatu yang lebih bernilai dan mampu membantu komunitas ini dalam meningkatkan penghasilan dan kesejahteraan mereka dimasa pandemic saat ini. Setelah melalui berbagai pertimbangan maka diputuskanlah untuk mengolah daging ikan lele menjadi Abon Lele dengan merek Abon Lele IndoFish.
\end{abstract}

Kata Kunci: UMKM, Komunitas, Abon

\begin{abstract}
The development of MSMEs in North Sumatra is quite good, namely around 2.8 million business units, and has contributed quite well to economic growth in North Sumatra and Medan in particular. MSMEs in the city of Medan are not seen as an alternative, but have become the backbone or foundation of the economy in Medan. There are 3 (three) things that must be considered and improved to strengthen the foundations of MSMEs, namely, finance, increase in human resources, and innovation in marketing models.

The Yoppie Belawan Community is one of the home industries in Medan Belawan District. Precisely on Jalan Selebes Belawan II, Medan Kota Belawan, North Sumatra 20411. Since the beginning of 2020, the Yoppie Belawan Community started a catfish farming business. In April 2020, this community decided to process catfish meat into something more valuable and able to help this community increase their income and welfare during the current pandemic. After going through various considerations, it was decided to process catfish meat into Shredded Catfish with the IndoFish Shredded Catfish brand.
\end{abstract}

Key Word: MSMEs, community, Abon

\section{PENDAHULUAN}

\section{Latar Belakang Masalah}

Pelaku UMKM di Indonesia memiliki peran yang strategis dalam menggerakan roda perekonomian Negara Indonesia. Pemerintah sudah mengeluarkan paket kebijakan dan regulasi khusus untuk UMKM. Tahun 2007 terbit Inpres No. 6/2007 mengenai Paket Kebijakan Percepatan Pengembangan Sektor Rill dan Pemberdayaan UMKM. Inpres ini memuat poin-poin penting reformasi kebijakan 
yang terdiri dari: perbaikan iklim investasi, reformasi sektor keuangan, percepatan pembangunan infrastruktur, dan pemberdayaan UMKM. Dan Tahun 2008, terbit Undang-Undang No. 20 Tahun 2008 mengenai UMKM. Poin utama dalam UndangUndang ini adalah untuk mewujudkan pertumbuhan ekonomi, pemerataan, dan peningkatan pendapatan masyarakat, penciptaan lapangan kerja dan pengentasan kemiskinan. Melihat peran UMKM yang cukup besar dalam menciptakan lapangan kerja, keberadaannya dapat membantu Pemerintah dalam pengetasan kemiskinan dan meningkatkan kesejahteraan keluarga serta meningkatkan pendapatan nasional. Sektor UMKM memerlukan dukungan dari berbagai pihak mengenai bagaimana membangun strategi pemasaran yang efektif, efisien dan menjangkai konsumen secara global. Baik dukungan berupa akses media pemasaran, penguasaan teknologi media pemasaran, maupun dukungan dalam menggunakan transaksi yang aman menggunakn media pemasaran online. Selama ini, pelaku UMKM masih masih memanfaatkan strategi pemasaran dengan informasi peluang dari mulut ke mulut. Strategi ini masih kurang efektif, dikarenakan pasar telah mengalami perubahan dan persaingan juga semakin ketat. Masing-masing pelaku usaha berlomba-lomba untuk menawarkan produknya dengan segala keunggulan yang dimiliki. Untuk dapat mengetahui keinginan dan kebutuhan konsumen diperlukan adanya survei pasar. Dengan melakukan survei pasar maka pelaku usaha akan mendapatkan informasi pasar dengan cepar dan tepat, informasi pasar dapat diperoleh dengan menggunakan internet yang cakupannya tidak hanya lokal tapi sudah berskala dunia karena dunia internet adalah dunia tanpa batas.

Selain itu, UMKM di Indonesia juga berkontribusi besar terhadap produk domestic bruto (PDB). Dimana UMKM Indonesia menyumbangkan hingga Rp 8.573.9 triliun ke PDB pada tahun 2018. Jumlah PDB Indonesia pada tahun 2018 sebesar Rp 14.838.3 triliun maka jumlah kontribusi UMKM mencapai 57.8\% terhadap PDB. Sedangkan untuk wilayah kota Medan UMKM merupakan salah satu kekuatan pendorong ekonomi. Perkembangan UMKM di Sumatera Utara cukup baik, yaitu sekitar 2.8 juta unit usaha, dan memberikan kontribusi yang cukup baik bagi pertumbuhan ekonomi di Sumatera Utara dan Medan pada khususnya.

UMKM di pandang dikota Medan tidak dipandang sebagai alternatif akan tetapi sudah menjadi tulang punggung atau pondasi dari ekonomi di Medan. Para pelaku UMKM dapat menghasilkan barang yang baru ketika mereka tidak lagi menghasilkan barang yang selama ini diproduksi. Kemampuan dalam mengubah atau 
mengganti barang yang dihasilkan inilah yang membuat UMKM mampu bertahan di ketika Negara mengalami krisis ekonomi saat ini. Terdapat 3 (tiga) hal yang harus diperhatikan dan diperbaiki untuk memperkuat pondasi dari UMKM yaitu, keuangan, peningkatan sdm, dan inovasi model pemasaran. Faktor keuangan harus dipisahkan antara modal dan bukan modal. Kemudian biaya produksi juga harus lebih selektif dipilih, mana yang harus diproduksi mana yang tidak. Yang bertujuan untuk mengurangi biaya produksi yang besar. Selain dari itu, pelaku UMKM juga harus diberikan bekal pengetahuan yang luas dalam memanfaatkan teknologi pemasaran untuk meningkatkan kinerja pemasarannya dengan menggunakan media internet. Pelaku UMKM diharapkan mampu mengelola seluruh potensi yang dimilikinya dengan memperhatikan hulu dan hilir dengan lebih jelas dan matang.

Kecamatan Medan Belawan merupakan salah satu dari 21 kecamatan yang ada di Kota Medan, Sumater Utara. Kecamatan Medan Belawan berbatasan dengan kabupaten Deli Serdang sebelah barat. Pada tahun 2018, kecamatan Medan Belawan dihuni oleh 99.273 orang penduduk dimana penduduk terbanyak dikelurahan Belawan II yakni sebanyak 21.686 orang. Jumlah penduduk terkecil di kelurahan Belawan Bahagia sebanyak 12.334 orang. Jumlah penduduk kecamatan Medan Belawan terdiri dari 49.067 orang laki-laki dan 50.206 orang perempuan. Berdasarkan kelompok umur, distribusi penduduk kecamatan Medan Belawan relatif lebih banyak penduduk usia produktif. Sebagai kecamatan yang merupakan pelabuhan terbesar di Sumatera Utara, maka sebagian besar penduduk di kecamatan Medan Belawan berkerja di sektor jasa yaitu sebagai kuli angkut di pelabuhan, berdagang, buruh pabrik ikan, dan sebagai nelayan. Pada saat ini, sudah mulai bermunculan perusahaan industri di kecamatan Medan Belawan. Perusahaan industri didominiasi oleh industri rumah tangga. Tercatat 16 industri besar, 70 industri sedang, dan 283 industri rumah tangga.

Komunitas Yoppie Belawan merupakan salah satu industri rumah tangga yang ada di Kecamatan Medan Belawan. Tepatnya di jalan Selebes Belawan II, Medan Kota Belawan, Sumatera Utara 20411. Komunitas Yoppie Belawan ini sejak awal tahun 2020 memulai usaha budidaya Ikan Lele. Jumlah kolam ikan lele yang dimiliki oleh komunitas ini sebanyak 3 kolam dengan ukuran 3 x 4 meter per kolam. Setiap kolam diisi dengan 5.000 ikan lele.

Pada April 2020, ketika virus Corona melanda dunia dan berdampak juga pada Komunitas Yoppie Belawan. Hasil penjualan ikan lele mengalami penurunan dan biaya 
operasional pemiliharaan ikan semakin meningkat. Selama ini ikan lele yang siap panen selalu dipasarkan di pasar-pasar tradisional yang ada dikecamatan Medan Belawan. Rendahnya penjualan pada saat itu memaksa komunitas ini untuk menjual ikan lele ke tengkulak untuk meningkatkan penjualan akan tetapi harga yang ditawarkan sangat rendah.

Pada akhirnya, komunitas ini memutuskan untuk mengolah daging ikan lele menjadi sesuatu yang lebih bernilai dan mampu membantu komunitas ini dalam meningkatkan penghasilan dan kesejahteraan mereka dimasa pandemic saat ini. Setelah melalui berbagai pertimbangan maka diputuskanlah untuk mengolah daging ikan lele menjad Abon Lele. Berdasarkan hasil survei yang dilakukan komunitas Yoppi Belawan sampai saat ini belum ada usaha rumah tangga yang menghasilkan Abon lele di Kecamatan Medan Belawan. Selain dari itu, usaha untuk mengolah daging ikan lele menjadi abon adalah untuk mengurangi kebosanan masyarakat terhadap olahan ikan lele yang selama ini hanya di goreng dan dibakar. Daging ikan lele mengandung sejumlah protein yang cukup tinggi dibandingkan dengan ikan-ikan tawar lainnya. Kandungan protein yang ada didaging ikan lele terdiri dari lemak sebesar 1,1 gram/100 gram, protein sebesar 18,7 gram/100 gram; vitamin B1 sebesar 0,1 mg dan vitamin B2 sebesar 0,05 mg; fosfor sebesar 260 gram/100 gram; serta omega 3. Secara umum semua ikan adalah sama, yaitu merupakan sumber asma lemak omega seperti asam lemak dengan ikatan rangkap pada posisi karbon.

Salah satu jenis ikan yang selalu berhibernasi dan diketahui memiliki kadar lemak yang tinggi adalah ikan lele. Oleh karena itu, mengapa ikan lele yang paling memiliki rasa yang paling gurih. Kualitas protein dari ikan lele tergolong sempurna (protein lengkap), mengandung semua asam amino esensial yang sangat berguna untuk menjaga kesehatan tubuh. Masalah yang terjadi sekarang adalah proses masak yang dilakukan masyarakat pada umumnya sekarang adalah dengan menggoreng lele, yang dapat menyebabkan asam amino esensial yang terdapat dalam lele larut bersama minyak, maka dibutuhkan pengolahan lain untuk memasak ikan lele.

Salah satu pengolahan ikan lele adalah dengan mengolahnya menjadi abon. Tujuan dari pengolahan abon lele ini adalah untuk meningkatkan minat masyarakat untuk mengkonsumsi ikan lele, dengan kandungan vitamin yang terdapat pada ikan lele dapat dimanfaatkan dengan baik. Pembuatan abon lele tergolong mudah dan tidak memakan waktu yang lama dalam proses pembuatannya. Abon lele ini akan dipasarkan 
ke masyarakat luas karena dapat bertahan beberapa hari dan bulan. Abon lele juga dapat dijadikan alternatif makanana pilihan dengan protein yang tinggi dibandingkan mengkonsumsi daging ayam dan sapi. Abon lele umumnya harganya lebih murah dibandingkan dengan abon ayam dan sapi

Proses pengolahan daging ikan lele menjadi Abon Lele yang dilakukan oleh komunitas Yoppie Belawan masih sangat sederhana dengan menggunakan peralatan rumah tangga. Dan jumlah Abon Lele yang diproduksi masih berdasarkan pesanan sehingga tidak setiap hari komunitas ini menghasilkan Abon Lele. Daging ikan lele di rebus/kukus selama 15 menit. Setelah direbus atau dikukus kemudian memisahkan daging ikan lele dari kulit luar ikan, tulang ikan, dan duri. Proses pemisahan daging ikan lele membutuhkan waktu yang cukup lama karena dibutuhkan ketelitian dan kehati-hatian agar daging benar-benar terpisah dari duri halusnya. Melihat potensi yang dimiliki oleh komunitas Yopie Belawan dalam mengembangkan usaha Abon Lele dapat memberikan kesejahteraan bagi anggota komunitas ini dan memberikan tambahan penghasilan. Komunitas ini dapat mengarahkan masyarakat untuk lebih menyukai memakan ikan karena ikan memiliki kandungan protein dan vitamin yang baik bagi tubuh manusia.

\subsection{Identifikasi dan Perumusan Masalah (12 pt+Bold)}

Berdasarkan survei lapangan ke komunitas Yope Belawan yang ada di Kecamatan Medan Belawan, maka dapat disimpulkan bahwa masalah yang dihadapi komunitas ini adalah:

1. Pengetahuan dan ketrampilan dalam proses pengemasan barang masih sangat minim

2. Pengetahuan mengenai pemasaran barang masing sangat mini

3. Tingkat pendidikan sumberdaya manusia dikomunitas ini masih sangat rendah Melihat potensi yang dimiliki oleh komunitas Yope Belawan dalam mengembangkan usaha Abon Lele dapat memberikan kesejahteraan bagi anggota komunitas ini dan memberikan tambahan penghasilan. Komunitas ini dapat mengarahkan masyarakat untuk lebih menyukai memakan ikan karena ikan memiliki kandungan protein dan vitamin yang baik bagi tubuh manusia. 


\subsection{Tujuan Pengabdian}

Tujuan dari pengabdian ini adalah untuk membantu komunitas dalam pengolahan abon lele untuk meningkatkan minat masyarakat dalam mengkonsumsi ikan lele, dengan kandungan vitamin yang terdapat pada ikan lele. Dan untuk membantu komunitas Yope Belawan dalam memasarkan atau mempromosikan Abon Lele yang dihasilkan melalui media sosial Instagram serta meningkatkan penghasilan dan kesejahteraan mereka dimasa pandemic komunitas Yope Belawan.

\subsection{Manfaat Pengabdian}

Manfaat dari pengabdian ini adalah untuk membantu komunitas Yope Belawan dalam meningkatkan penjualan melalui pemasaran dan promosi yang dilakukan dengan menggunakan media sosial Instagram yang dimiliki.

\section{TINJAUAN PUSTAKA}

\section{Pengertian Komunitas}

Komunitas berasal dari bahasa latin communitas yang berarti "kesamaan" kemudian dapat diturunkan dari communis yang berarti "sama, publik dibagi oleh semua atau banyak”. Menurut Mac Iver dalam Mansyur, community diartikan sebagai persekutuan hidup atau paguyuban dan dimaknai sebagai suatu daerah masyarakat yang ditandai dengan beberapa tingkatan pertalian kelompol sosial satu sama lain. Keberadaan komunitas didasari oleh beberapa hal, yaitu;

1. Lokalitas

2. Sentiment Community

Unsur-unsur dalam sentiment community, adalah:

1. Seperasaan

Unsur seperasaan muncul akibat adanya tindakan anggota dalam komunitas yang mengidentifikasi dirinya dengan kelompok dikarenakan adanya kesamaan kepentingan.

2. Sepenanggungan

Sepenanggungan diartikan sebagai kesadaran akan peranan dan tanggung jawab anggota komunitas dalam kelompoknya

3. Saling memerlukan

Unsur saling memerlukan diartikan sebagai perasaan ketergantungan terhadap komunitas baik yang bersifat fisik maupun psikis. 


\section{Pengertian Pemasaran}

Pemasaran merupakan salah satu dimana dari kegiatan yang dilakukan oleh suatu usaha dan merupakan faktor yang sangat penting bagi perusahaan untuk dapat menyebarkan informasi dan menyampaikan hasil produknya agar diterima oleh konsumen. Adapun pengertian pemasaran menurut para ahli, yaitu:

1. Menurut Swastha (2002:10) Pemasaran adalah suatu sistem keseluruhan dari kegiatan-kegiatan bisnis yang dibuat untuk merencanakan, menetapkan harga, mempromosikan dan mendistribusikan barang atau jasa yang dapat memuaskan kebutuhan pelanggan yang ada kepada pembeli yang potensial.

2. Menurut Bloom \& Boone (2006 : 5) Pemasaran adalah sebuah fungsi manajemen penting yang diperlukan guna menciptakan permintaan produk yang Anda jual. Konsep utama pemasaran adalah pertukaran nilai antara dua kelompok: pembeli dan penjual.

3. Menurut Malau (2017 : 1) Pemasaran (Marketing) merupakan kegiatan transaksi pertukaran nilai yang dimiliki oleh masing-masing pihak, misalnya pertukaran produk yang dimiliki oleh perusahaan terhadap uang yang dimiliki oleh pelanggan.

\section{Pengertian Promosi}

Promosi adalah salah satu kegiatan dalam bauran pemasaran (marketing mix) yang sangat penting yang dilakukan oleh perusahaan dalam memasarkan produk atau jasanya kepada calon pembeli potensial dengan tujuan untuk memberitahu, memperkenalkan, menarik, dan membujuk calon pembeli untuk membeli barang atau jasa yang ditawarkan. Pengertian promosi menurut beberapa ahli, yaitu:

1. Bloom \& Boone (2006 : 8) Promosi bermaksud untuk menginformasikan dan membujuk target konsumen dalam hal nilai dari produk yang dijual. Sarana promosi utama adalah melalui iklan, penjualan secara pribadi, publikasi, dan promosi penjualan. Penentuan tentang media mana yang akan digunakan juga merupakan bagian yang penting dari sebuah promosi produk.

2. Abdullah (2016 : 239) Promosi penjualan merupakan upaya pemasaran yang bersifat media dan nonmedia untuk merangsang bangkitnya coba-coba dari konsumen, meningkatkan permintaan dari konsumen atau untuk memperbaiki kualitas produk. 
3. Malau (2017 : 102) Promosi adalah bentuk dari persuasi langsung melalui penggunaan berbagai insentif yang dapat diatur untuk merangsang pembelian produk dengan segera dan/atau meningkatkan jumlah barang yang dibeli pelanggan.

\section{Pengertian Pemasaran Media Sosial}

Menurut Tsitsi (2013) pemasaran media sosial adalah sistem yang memungkinkan pemasar untuk terlibat, berkolaborasi, berinteraksi, dan memanfaatkan kecerdasan orang-orang yang berpartisipasi didalam tujuan pemasaran, menarik perhatian dan mendorong pembaca untuk berbagi jaringan sosial mereka. Menurut Neti (2013), Keuntungn dalam menggunakan pemasaran media sosial adalah:

1) Menyediakan ruang dangan tidak hanya untuk memasarkan produk atau jasa kepada pelanggan tetapi juga untuk mendengarkan keluhan dan saran.

2) Mempermudah untuk mengidentifikasi berbagai kelompok atau pengaruh antara berbagai kelompok, yang dapat menjadi pemberi informasi tentang merek dan membantu dalam growth of brand (pertumbuhan merek).

3) Biaya rendah kerena sebagian besar situs jejaring sosial gratis

\section{Pengertian Instagram}

Instagram adalah salah satu media sosial yang banyak digunakan individu dalam hal berbagi foto dan video singkat antar individu yang lainnya. Dapat juga digunakan sebagai media komunikasi online untuk berbagi dan mendapatkan informasi. Menurut Makmur (2016 : 40) instagram lebih fokus kepada image/foto yang telah diambil dengan menggunakan kamera handphone. Dengan menggunakan instagram tentunya produk yang diiklankan akan memiliki nilai lebih ketika diperlihatkan dalam account instagram. Karena foto yang diambil langsung menggunakan kamera handphone sendiri.

\section{METODE PELAKSANAAN}

Kegiatan ini dilaksanakan pada bulan Desember 2020 di tempat komunitas Yope Belawan. Kegiatan ini hadiri oleh ketua komunitas Yope Belawan dengan beberapa anggota komunitas yang terlibat secara langsung dalam pembuatan dan pengolahan Abon Lele di Belawan. Secara rinci kegiatan pengabdian masyarakat dengan tema Pemberdayaan Usaha Abon Lele pada komunitas Yope Belawan dijelaskan sebagai berikut:

\section{Tahapan Presentasi}


1. Alat yang digunakan dalam penyampaian materi adalah infokus dan proyektor dengan tampilan slide powerpoint.

2. Penjelasan pemateri dilakukan dengan satu arah, dan setiap peserta menyimak paparan dari pemateri sembari mempersiapkan pertanyaan atau hal yang nantinya akan didiskusikan.

3. Materi yang diberikan berkaitan dengan proses pengemasan dan pemasaran Abon Lele dengan menggunakan media sosial serta pemberian merek atau nama dagang untuk Abon Lele yang siap untuk dipasarkan.

\section{Tahapan Diskusi}

1. Merupakan proses komunikasi dua arah antara pemateri dan anggota komunitas Yope Belawan dalam tahapan ini peserta secara bebas menyampaikan berbagai pertanyaan ataupun hal yang ingin didiskusikan terkait dengan pemaparan materi yang telah diberikan ataupun tema yang sedang didiskusikan dalam kegiatan ini.

2. Peserta secara tertib mulai memberikan berbagai pertanyaan terkait proses pengemasan dan pemasaran Abon Lele dengan menggunakan media sosial serta pemberian merek atau nama dagang sehingga proses kegiatan menjadi sangat aktif dan interaktif.

\section{HASIL DAN PEMBAHASAN}

Komunitas Yope memutuskan untuk mengolah daging ikan lele menjadi sesuatu yang lebih bernilai dan mampu membantu komunitas ini dalam meningkatkan penghasilan dan kesejahteraan mereka dimasa pandemic saat ini. Setelah melalui berbagai pertimbangan maka diputuskanlah untuk mengolah daging ikan lele menjad Abon Lele. Selain dari itu, usaha untuk mengolah daging ikan lele menjadi abon adalah untuk mengurangi kebosanan masyarakat terhadap olahan ikan lele yang selama ini hanya di goreng dan dibakar. Daging ikan lele mengandung sejumlah protein yang cukup tinggi dibandingkan dengan ikan-ikan tawar lainnya. Kandungan protein yang ada didaging ikan lele terdiri dari lemak sebesar 1,1 gram/100 gram, protein sebesar 18,7 gram/100 gram; vitamin B1 sebesar 0,1 mg dan vitamin B2 sebesar 0,05 mg; fosfor sebesar 260 gram/100 gram; serta omega 3. Secara umum semua ikan adalah sama, yaitu merupakan sumber asma lemak omega seperti asam lemak dengan ikatan rangkap pada posisi karbon. 
Pada gambar 1 merupakan proses perebusan ikan lele dengan menggunakan wadah yang mampu menampung ikan lele sebanyak $5 \mathrm{~kg}$ sekali perebusan atau pengukusan

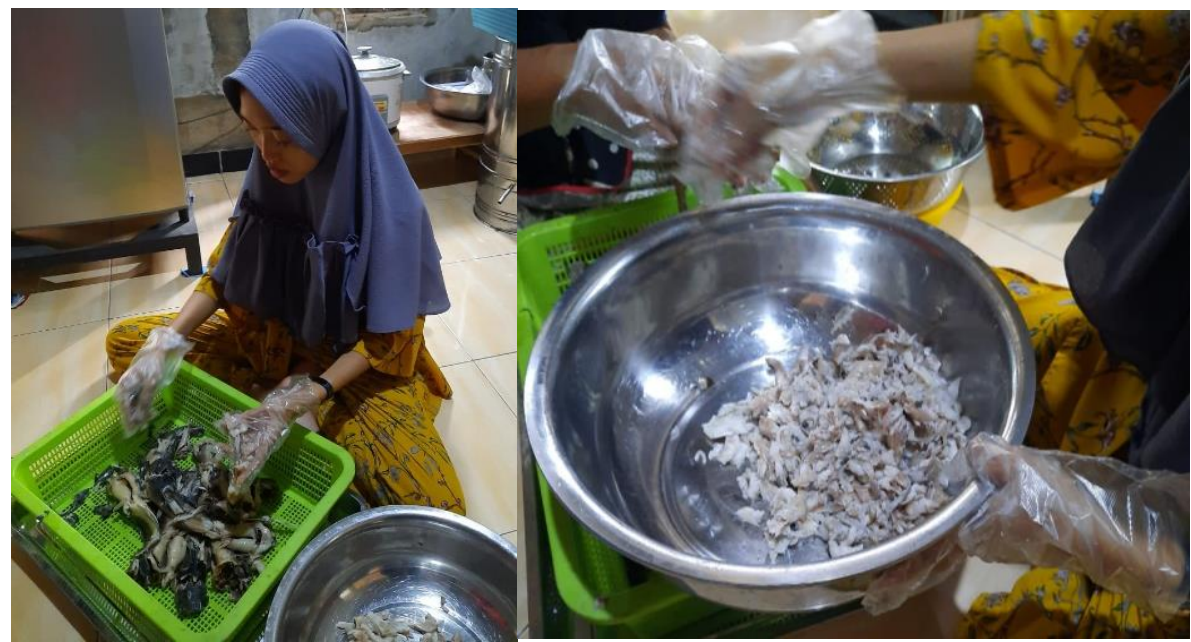

Gambar 1 Proses Perebusan Ikan Lele

Daging yang sudah terpisah tadi kemudian dicampur dengan berbagai bumbu untuk menambah cita rasa. Proses pencampuran bumbu terlihat pada gambar 3 setelah bumbu tercampur dengan rata kemudian dipindahkan kewadah penggorengan dan daging ikan yang tercampur dengan bumbu digoreng selama kurang lebih 1 jam.

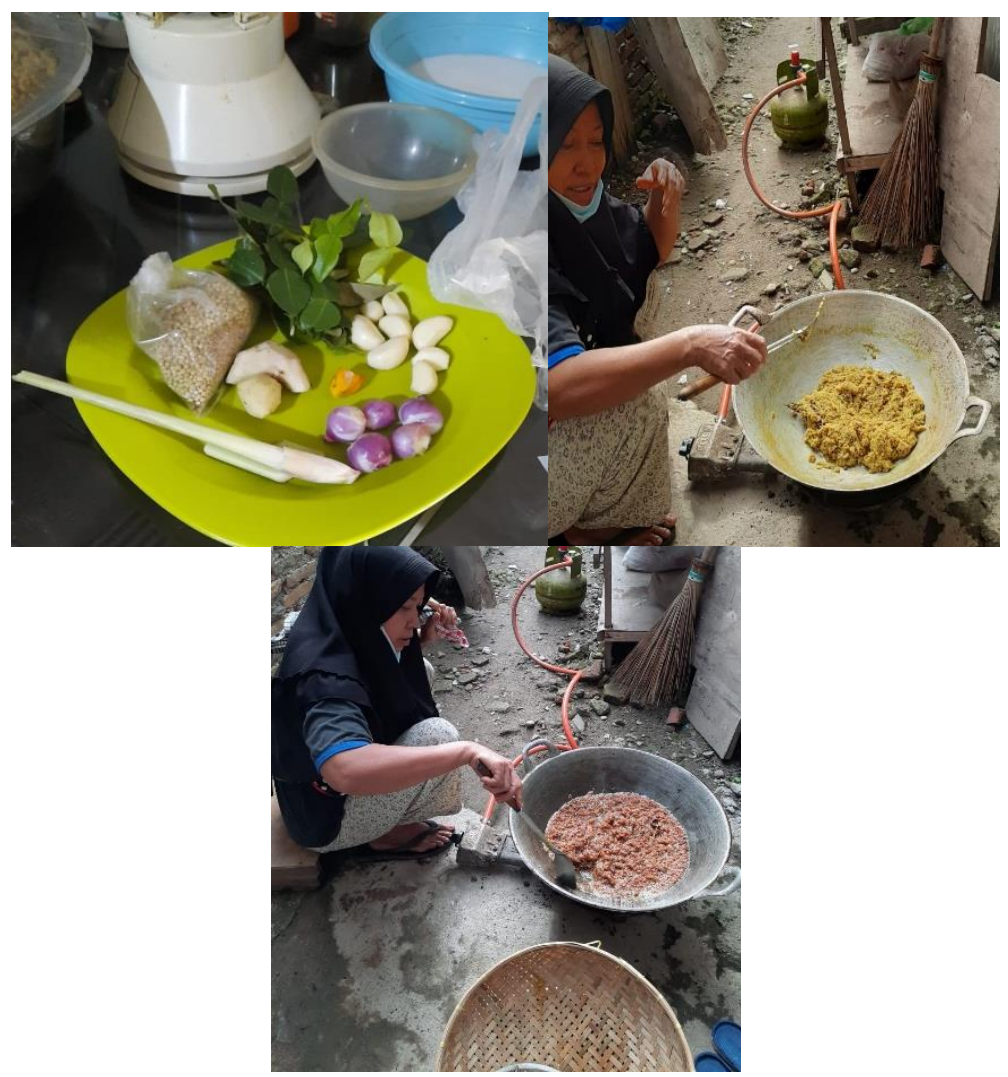




\section{Gambar 2 Proses Pencampuran Bumbu dan Penggorengan}

Setelah digoreng olahan Abon Lele dikeringkan dengan menggunakan mesin penggering yang masih sangat sederhana seperti pada gambar 3

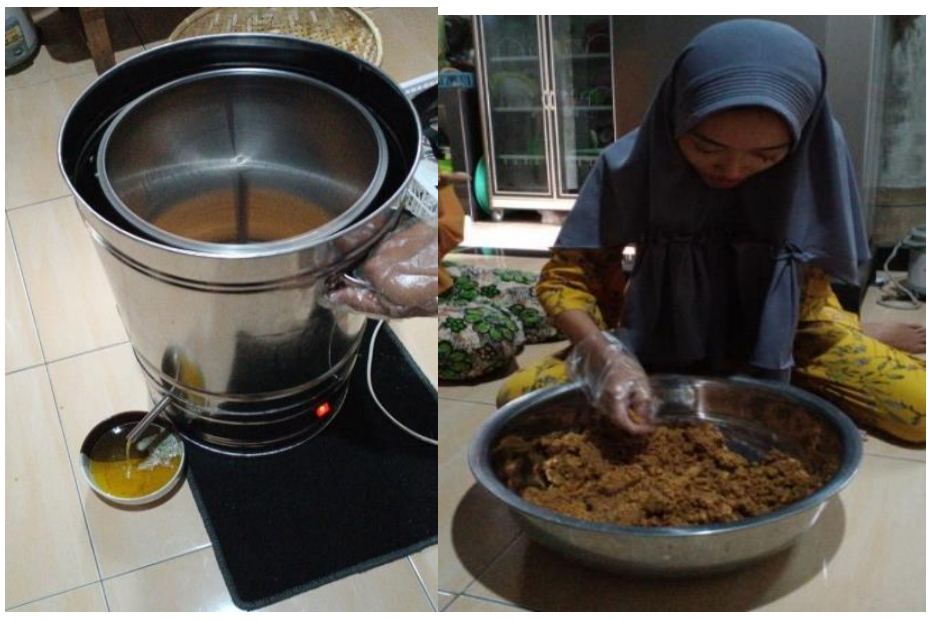

Gambar 3 Proses Pengeringan Abon Lele

Proses penggeringan dalam mesin membutuhkan waktu kurang lebih 15 menit. Setelah kering olahan Abon Lele menjadi mengeras dan agar kembali lunak maka dilakukan proses pelepasan olahan Abon Lele. Langkah selanjutnya adalah melakukan pengemasan Abon Lele kedalam kemasan yang masih sederhana dan belum memiliki merek. Bentuk kemasan yang gunakan komunitas ini adalah plastik dan toples dengan berat masing-masing 100 gram. Gambar pengemasan dan bentuk kemasan terlihat pada gambar berikut:

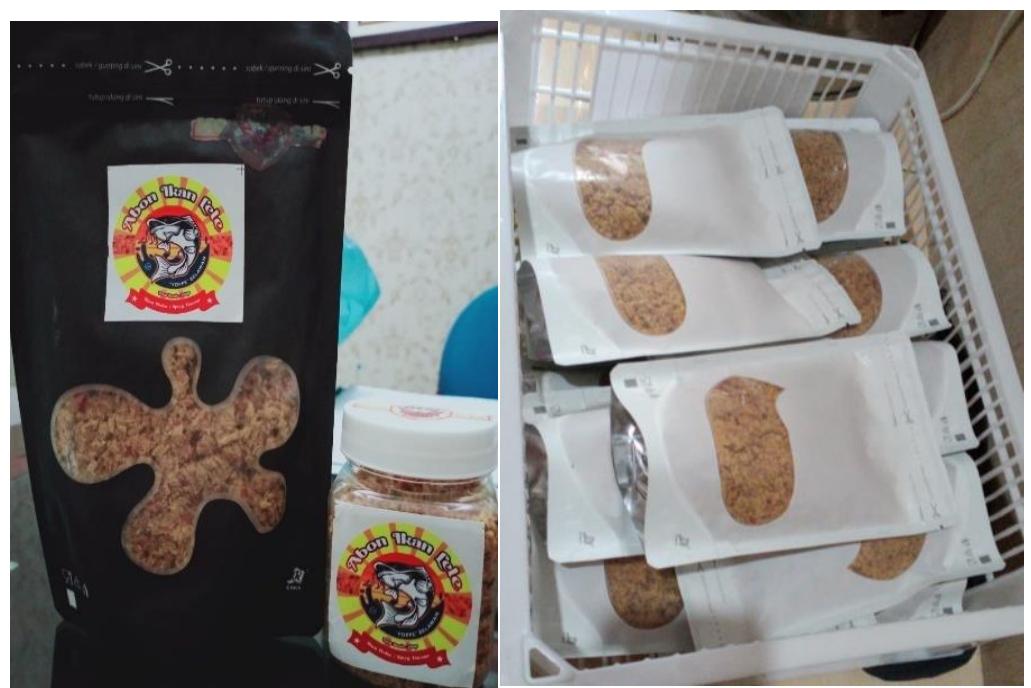

Gambar 4. Proses Pengemasan dan Bentuk Kemasan 
Setelah proses pengemasan Abon Lele siap untuk diantar kepesan. Bentuk media sosial yang digunakan sebagai alat pemasaran yang dibuat hasil dari diskusi dengan anggota komunitas Yope Belawan dalam bentuk Instagram. Instagram dipilih dikarenakan saat ini media sosial ini sangat digemari oleh masyarakat saat ini. Berikut gambar dari media sosial komunitas Yope Belawan:

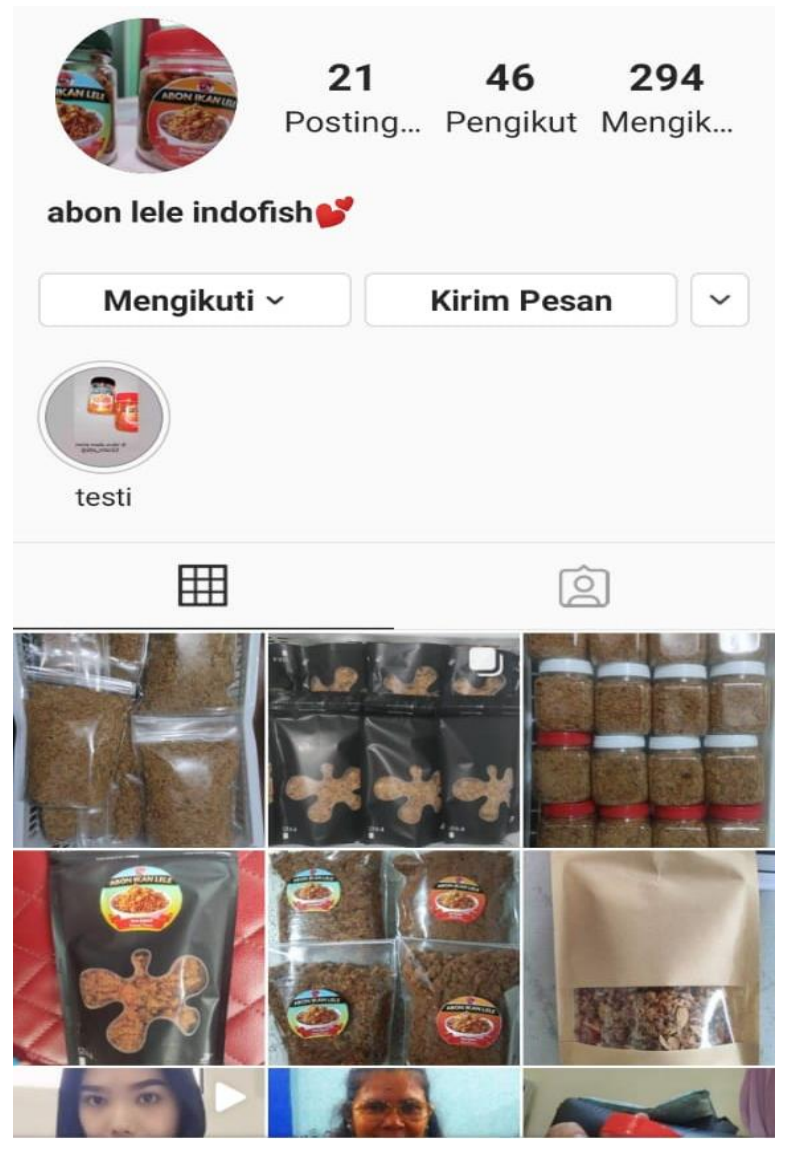

\section{KESIMPULAN}

Dari hasil kegiatan pengabdian yang dilakukan Komunitas Yope Belawan menyadari pentingnya melakukan prmosi pemasaran melalui media sosial dikarenakan saat ini media sosial banyak digunakan semua kalangan usia. Dan pemasaran melalui media sosial dapat menghemat biaya dan jangkauan pangsa pasar yang lebih luas yang dapat dicapai oleh Komunitas Yope. Dengan demikian, hasil akhir dari pengabdian ini adalah dibuatnya Instagram untuk komunitas Yope Belawan dalam memasarkan dan mempromosikan Abon Lele yang dihasilkan. 


\section{DAFTAR PUSTAKA}

Basu Swastha.2002. Manajemen Pemasaran. Edisi Kedua. Cetakan Kedelapan. Jakarta: Penerbit Liberty

Bloom dan Louise N. Boone. (2006). Strategi Pemasaran Produk: 18 Langka Membangun Jaring Pemasaran Produk Yang Kokoh. Prestasi Pustaka, Jakarta.

Malau Herman, 2017. Manajemen Pemasaran. Alfabeta, Bandung.

\section{Sumber Internet:}

Armyn Musyaddad, dkk. 2019. Produksi Abon Ikan Lele Sebagai Alternatif Usaha Untuk Meningkatkan Perekonomian Masyarakat Desa Pelutan. AJIE-Asian Journal of Innovation and Enterpreneuship. E-ISSN: 2477-0574;p-ISSN: 2477-3824), Vol 04, Issue 03.

Cholil Mansyur, Sosiologi Masyarakat Desa dan Kota, (Surabaya: Usaha Nasional, 1987) h. 69.

Abdullah, D.N.M.A \& Rozario, F. 2009. Influence of Service and Product Quality to wards Customer Satisfaction: A Case Study at the Staff Cafetaria in The Hotel industry. World Academy of Science, Engineering and Technology 53, 185190.

Tsitsi, et. Al. (2013). The Adoption of Social Media Marketing in South African Banks, European Business Review, vol. 25:4.

Neti, S. (2011). Social Media and It's Role in Marketing. International Journal of Enterprise Computing and Business Systems, 1(2).

https://medankota.bps.go.id/publication/download.html?

https://www.alodokter.com/tidak-sedikit-manfaat-ikan-lele 